\title{
Study of face pleasantness using facial analysis in standardized frontal photographs
}

\author{
Imara de Almeida Castro Morosini', Ana Paula Lazzari Marques Peron², Keila Rodrigues Correia ${ }^{3}$ Ricardo Moresca ${ }^{4}$
}

Objective: The purpose of this research was to check if the numeric facial analysis can determine facial attractiveness. Method: The sample consisted of frontal and lateral standard facial photographs, in natural head position, of 85 Brazilian Caucasian women, without facial plastic surgery report. The sample mean age was 23 years and 9 months. A group of 5 orthodontists, 5 layman and 5 plastic artists classified the photographs according to their own attractiveness graduation in: pleasant, acceptable and not pleasant. The numeric facial analysis was then performed using a computerized method. Linear, proportional and angular measurements were compared among groups. Results: According subjective analysis the sample was consisted of $18.8 \%$ of pleasant, $70.6 \%$ of acceptable and $10.6 \%$ of not pleasant. In most measurements there were no differences among groups. Just in three of them significant statistical difference was observed and in two of them the comparison value was within decision limit. All the differences found were related to the lower third of the face and to facial pattern. Conclusion: On the present research, the numeric facial analysis, by itself, was not capable of detecting facial attractiveness, considering that beauty judgment seems to be very personal.

Keywords: Facial analysis. Attractiveness. Facial esthetics.

Objetivo: esse estudo foi desenvolvido com o propósito de verificar se a análise facial numérica realizada em fotografias frontais é sensível em detectar a atratividade da face. Métodos: a amostra foi composta por fotografias faciais padronizadas, frontais e laterais, em posição natural da cabeça, de 85 mulheres brasileiras, leucodermas, com idades entre 18 e 30 anos, sem histórico de cirurgia plástica facial. A idade média da amostra foi de 23 anos e 9 meses. As fotografias foram classificadas de acordo com o grau de atratividade da face por uma banca composta de cinco especialistas em Ortodontia, cinco leigos e cinco artistas plásticos. A partir dessa classificação, os indivíduos foram divididos em três grupos: esteticamente agradáveis, esteticamente aceitáveis e esteticamente desagradáveis. Em seguida, foram realizados os traçados fotométricos por meio computadorizado. As médias das variáveis lineares, proporcionais e angulares propostas foram comparadas estatisticamente entre os grupos. Resultados: pela análise subjetiva, $18,8 \%$ da amostra foram classificados como esteticamente desagradáveis, 70,6\% como esteticamente aceitáveis e 10,6\% como esteticamente agradáveis. Na maioria das variáveis, não observou-se diferenças entre os grupos. Em apenas três delas houve diferenças estatisticamente significativas. Todas as diferenças encontradas relacionaram-se ao terço inferior da face e ao padrão facial. Conclusão: no presente estudo, a análise facial numérica utilizada isoladamente não foi sensível na detecção de padrões de atratividade, já que os critérios de beleza parecem ser altamente subjetivos.

Palavras-chave: Análise facial. Atratividade. Estética facial.

${ }^{1}$ Specialist in Orthodontics and MSc in Dentistry, UFPR. Professor of Specialization course in Orthodontics, Positivo University

${ }^{2}$ Specialist in Orthodontics, UFPR. MSc student in Orthodontics, PUC-PR. Professor of Specialization course in Orthodontics, Positivo University .

${ }^{3}$ Specialist in Orthodontics, UFPR.

${ }^{4} \mathrm{PhD}$ in Orthodontics, FOUSP. Associate Professor of Orthodontics, UFPR. Full Professor of MSc in Dentistry, Positivo University.
How to cite this article: Morosini IAC, Peron APLM, Correia KR, Moresca R. Study of face pleasantness using facial analysis in standardized frontal photographs. Dental Press J Orthod. 2012 Sept-Oct;17(5):24-34.

Submitted: July 27, 2008 - Revised and accepted: June 01, 2012.

» The authors report no commercial, proprietary or financial interest in the products or companies described in this article.

" Patients displayed in this article previously approved the use of their facial and intraoral photographs.

Contact address: Imara de Almeida Castro Morosini Av. Cândido Hartmann, 1465 - Bigorrilho - Curitiba/ PR - Brasil.

Zip code: 80.710-570 - E-mail: imaracastro@terra.com.br 


\section{INTRODUCTION}

Since the beginning of the 20th century, it has been observed in Orthodontics a great concern about esthetics, especially involving concepts of balance and facial proportions. . $^{21,27}$

Beauty criteria are highly subjective, reflecting cultural peculiarities of a population, the region where they live and a determined period of time. ${ }^{11}$ Over the years there were significant changes in facial esthetic standards, so orthodontists must be updated about what the population considers an ideal face. ${ }^{20}$

From the patient's point of view, esthetics is the main motivation for seeking orthodontic treatment. ${ }^{26,28}$ For this reason it is recommended that orthodontic treatment is planned starting from a global evaluation of the face, paying attention to esthetic necessities as well as to cephalometric and functional matters.

Through diagnosis, the professional must try to identify the unpleasant facial characteristics which can be improved with the orthodontic treatment, as well as the aspects considered pleasant and must be preserved during treatment. It is important, however, that this evaluation consider the ethnical and personal characteristics of the patient, trying to use the same esthetic evaluation parameters of the patient and the society in which he belongs.

Several studies were developed focusing both numerical and subjective facial analysis,

Aiming to establish reference values for facial measurements and to verify esthetical tendencies of the studied populations. ${ }^{1,3,4,5,7-11,16,22,23,26}$

Some authors evaluated esthetics through clinical exams and measurements directly on the face. $^{3,8,25}$ Studies with laser scanning techniques ${ }^{16}$ and computerized methods ${ }^{17,18}$ were also performed. Other authors chose to use facial photographs to evaluate esthetics, ${ }^{4,9}$ considering that photographs allow a more accurate evaluation of measurements and proportions, which would be difficult directly on the face.

Photographs allow the observation of harmonious relation between soft and hard facial tissues, also considering adipose tissue, besides not exposing the patient to radiation and having a very low cost. ${ }^{9}$

This study was developed to evaluate facial at- tractiveness and facial characteristics of women in a frontal view through standardized photographs, in order to:

1) Characterize the studied sample according to subjective concepts of facial esthetics in esthetically pleasant, esthetically acceptable and esthetically unpleasant, considering frontal and lateral photographs together.

2) Verify agreement level between subjective evaluations conducted by orthodontists, plastic artists and laypeople.

3) Verify the possible differences between means of the variables proposed in the three studied groups, considering only frontal photographs.

4) Verify whether the numerical frontal facial analysis is sensitive to detect facial attractiveness.

\section{MATERIAL AND METHODS Material \\ Sample}

The present study was part of a series of performed researches with the objective of studying the facial esthetics in women, applying several facial analysis, both numerical and proportional.

Standardized facial photographs from 85 individuals of female gender,Brazilians, Caucasians, living in the city of Curitiba, from 18 to 30 years old, without previous facial plastic surgery were used. The mean age of the sample was of 23 years and 9 months \pm 3 years and 2 months. All individuals voluntarily participate in the research and signed a Term of Informed Free Consent, which informed them about the study intentions.

\section{Methods \\ Photographs}

To obtain the photographs (frontal and lateral) individuals were sat and, looking directly to the eyes reflected in the mirror in front of them, ${ }^{6,14,30}$ keeping an upright and normal posture, with both arms free along the body. ${ }^{9}$ This position corresponds to the "Broca's Natural Head Position".

Behind individuals were placed a white screen to standardize the background, this way the ambiance would not influence photographs evaluation. For true vertical reference it was used a plumbline. ${ }^{14}$

The camera was placed on a Vivitar tripod to stan- 
dardize the distance between it and the individual, also avoiding undesirable movements of operator while taking photographs. Configuring the camera, focal length, Shutter Speed and lens aperture were, respectively, $1.70 \mathrm{~m}, 1 / 200$ and $\mathrm{F} 29$. It was used ring flash as source of light. ${ }^{5,22,26}$ To verify correlation between real measurements and measures from the photographs, two reference points were marked in the forehead of 5 individuals distancing $1 \mathrm{~cm}$ from each other. ${ }^{5}$ After photographs revelation, the marks were measured and the value of $0.4 \mathrm{~cm}$ was obtained. It could be concluded in this sample that photographs corresponded to $40 \%$ of the real size.

The photographs were printed in the same QLab studio (international Kodak quality standard) in $10 \mathrm{x}$ $15 \mathrm{~cm}$ size, color, matte paper.

\section{Method of sample classification}

The photographs were presented to 15 examiners divided into 3 groups:

5 specialists in Orthodontics, 5 laymen in Orthodontics and not related to the arts and 5 plastic artists. The mean age of evaluators was 44 years and 8 months \pm 10 years and 8 months.

Evaluators were instructed to assign a value ranging from 1 to 9 to each participant using their own esthetics criteria, always considering the two photographs together. Value 1 meant the lowest facial attractiveness and 9 the highest level os facial attractiveness. They were instructed to do all evaluations at the same time.

After results tabulation, it was calculated the means for each one of the 85 individual and they were classified into 3 groups according to the facial attractiveness, being:

» Group 1: Esthetically pleasant (score 1, 2, 3 or 4);

» Group 2: Esthetically acceptable (score 5 or 6);

» Group 3: Esthetically pleasant (score 7, 8 or 9).

\section{Facial analysis}

The photometric tracings were performed only in frontal photographs, by the same trained observer, not from the group in charge of subjective evaluations, using a computerized method. For this purpose, it was used the software Radiocef Studio $2^{\circledR}$, in which was developed a frontal facial analysis with the Mixcef tool.

The photographs were saved in JPEG format and uploaded directly to the software, with 300 dpi resolution. Aiming a better identification of the points, the software had also a tool for enlarging the image, which was used by the professional when it was needed.

\section{Photometric points}

Photometric points used are displayed in Figure 1.

\section{Linear measures}

Linear measures are represented in Figures 2, 3 and 4, with its descriptions.

\section{Proportional measures}

1) Facial index: Is the proportion between the facial height (N'-Me') and the upper facial width (Zid'-Zie') (Fig 5).

The Facial Index determines the facial type and is calculated this way:

\section{facial height $x 100$}

upperfacial width

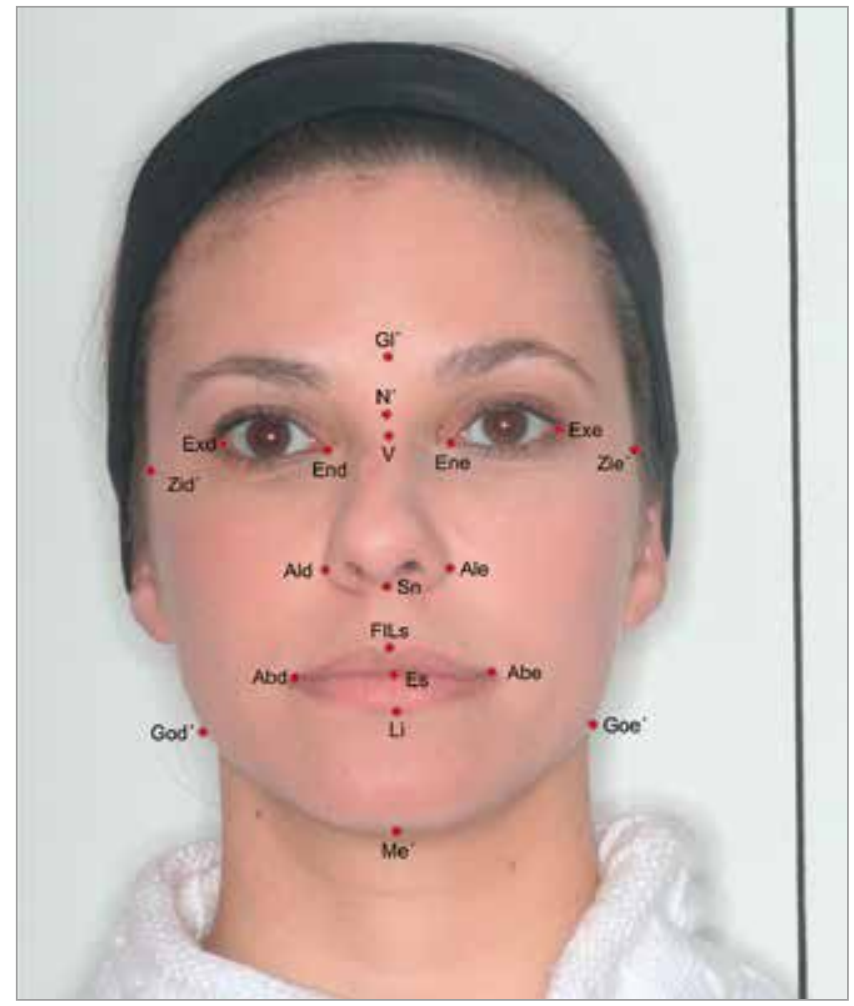

Figure 1 - Photometric Points: Gl' - soft tissue glabella; N' - soft tissue nasion; Exd-right external corner of the eye; Exe - left external corner of the eye; End - right internal corner of the eye; Ene - left internal corner of the eye; $\mathrm{V}$ - Point $\mathrm{V} ; \mathrm{Sn}$ - subnasale; Ald - right alar poit; Ale - left alar point; F- lower philtrum; Ls- upper philtrum; Li- lower lip; Abd- right mouth angle; Abe - left mouth corner; Es- stomium; Zid - right zigion; God'- right gonion; Goe'- left gonion; Me'- Menton. 


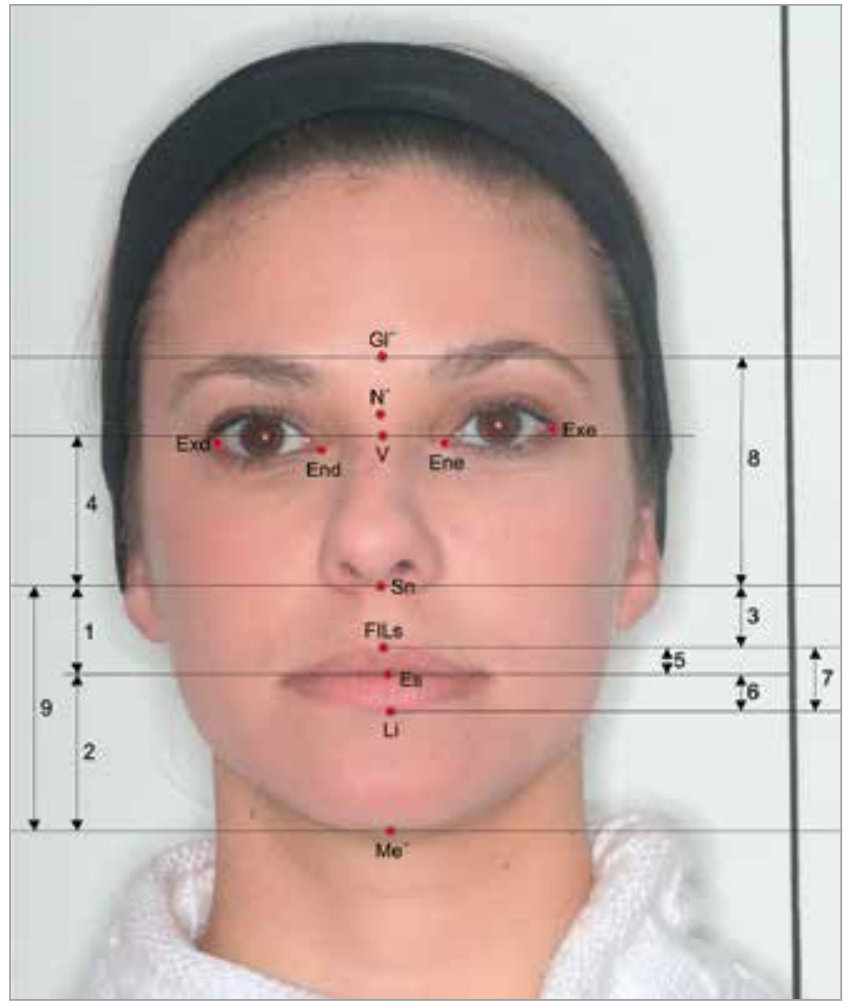

Figure 2 - Linear measurements from 1 to 9: 1) Upper lip length (Sn-Es); 2) Lower lip length (Es-Me'); 3); Philtrum length (Sn-U1); 4) Nose prominence ( $\mathrm{V}$ - Sn); 5) Vermilion border of the upper lip ( Ul-Es); 6) Vermilion border of the lower lip (Es-LI); 7) Mouth heigth (UI-LI); 8) Middle facial height (Gl' to Sn); 9) Lower facial height (Sn to $\mathrm{Me}^{\prime}$ ).

2) Facial Height Proportion: The proportion between Middle facial height (Gl'-Sn) and lower facial height (Sn-Me') (Fig 5).

\section{Angular measures}

Angular measurements used are shown in Figures 6 and 7, with their respective descriptions.

For the angle of facial symmetry the midline of the face was defined by the nasion ( $\left.\mathrm{N}^{\prime}\right)$ and filter (F).

\section{Statistical Analysis}

Comparisons between numerical measurements obtained in the 3 groups (esthetically pleasant, acceptable and unpleasant) were performed using ANOVA and Kruskal-Wallis test, with the software "Primer of Biostatistics" The significance level was of $5 \%(\mathrm{p}<0.05)$.

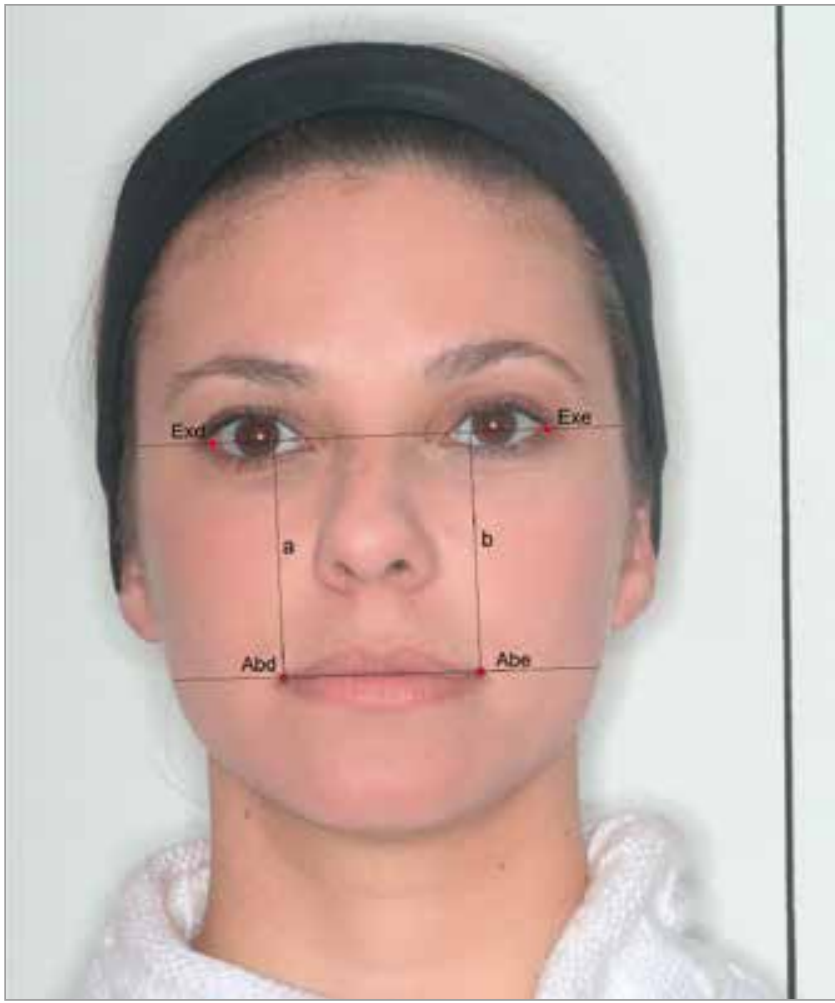

Figure 3 - Linear measurement 10: Commissure line inclination - difference, in millimeters, from the commissure line to the line joining the external corners of the eyes at Abd point height (a) and at Abe point height (b).

To verify concordance level between evaluations of different groups, Kappa index was used and the percentage of reviewers agreeing by the Minitab software, 2007 version (www.minitabbrasil.com.br).

\section{Error of method evaluation}

The Error of method analysis was performed by repeating the marking points of the same operator, followed by measurement of factors by Radiocef Studio 2 software and 20 photographs of the sample, randomly selected. The interval between evaluations was of 1 week.

To check the systematic error, data obtained from first and second measurements were submitted to Student's t test and to Wilcoxon test for paired samples, significance level of $5 \%$. To evaluate casual error, the Dahlberg formula was used. 


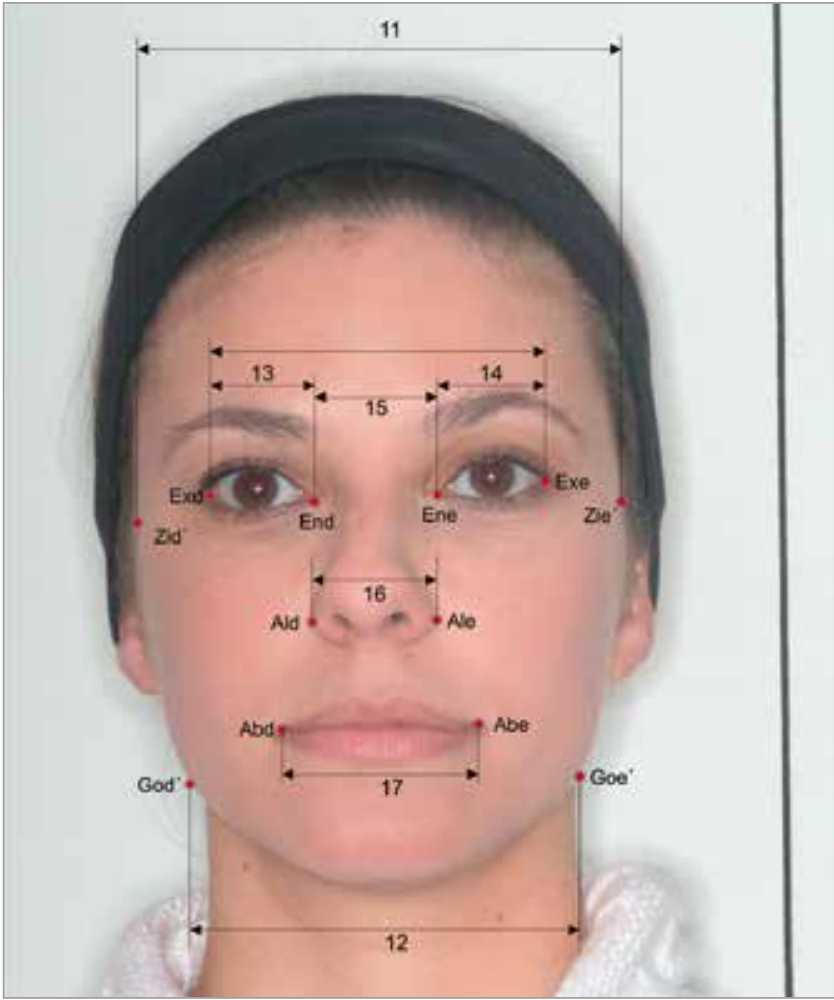

Figure 4 - Linear measures 11 to 17: 11) Upper facial width (Zid' and Zie'); 12) Lower facial width (God' and Goe'); 13) Right eye width (Exd to End); 14) Left eye width (Exe to Ene); 15) intercanthal distance (End to Ene); 16) Nasal width (Ald to Ale); 17) Mouth width (Abd to Abe).

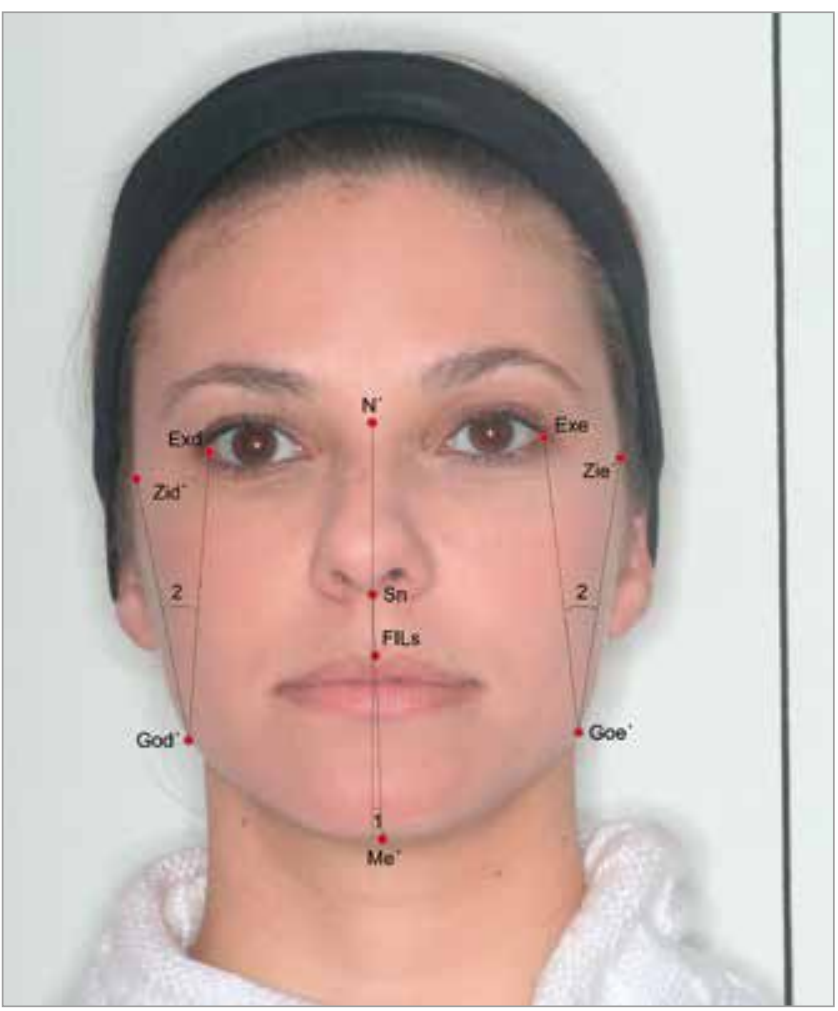

Figure 6 - Angular measures 1 and 2: 1) Facial symmetry angle - angle formed between facial midline ( $\left.\mathrm{N}^{\prime}-\mathrm{F}\right)$ and $\mathrm{Sn}^{\prime} \mathrm{Me}^{\prime}$ line 2) Symmetry between left and right side of the face - the difference between left and right angle measurements formed by intersection of $\mathrm{Zi}^{\prime}-\mathrm{Go}$ and $\mathrm{Ex}-\mathrm{Go}$ ' lines

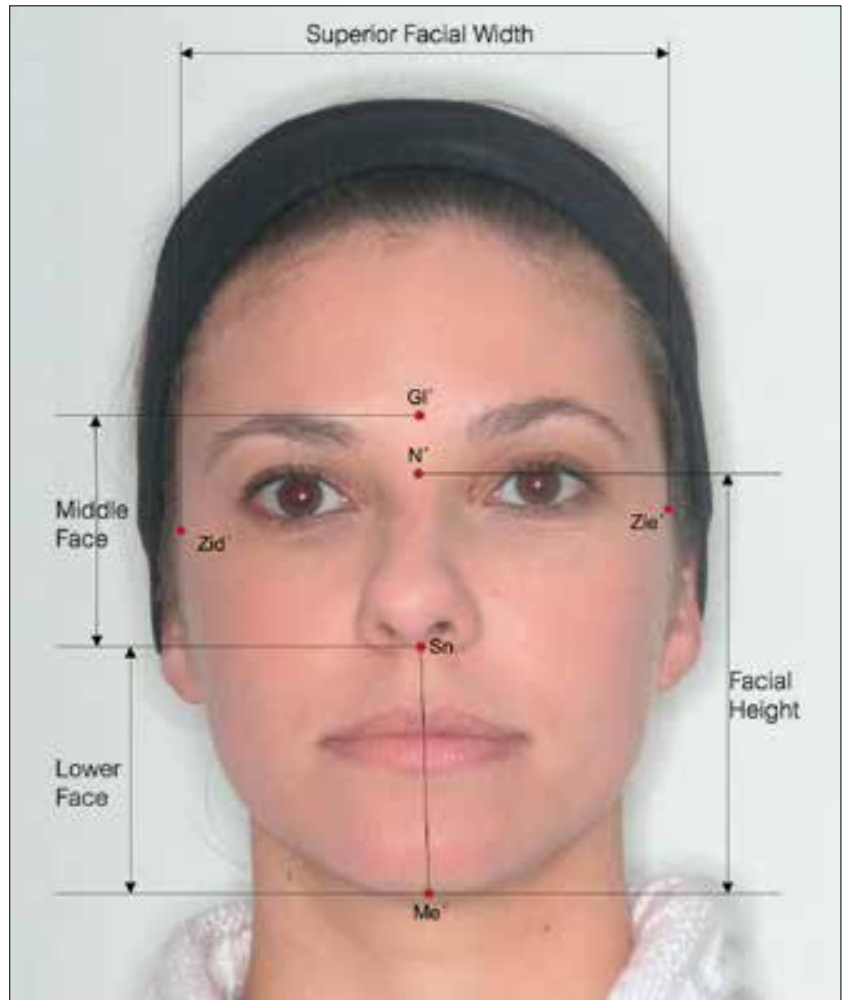

Figure 5 - Proportional measures - Facial Index: Proportion between upper facial height and facial width; Facial Height Proportion: Proportion between middle face height and lower face height.

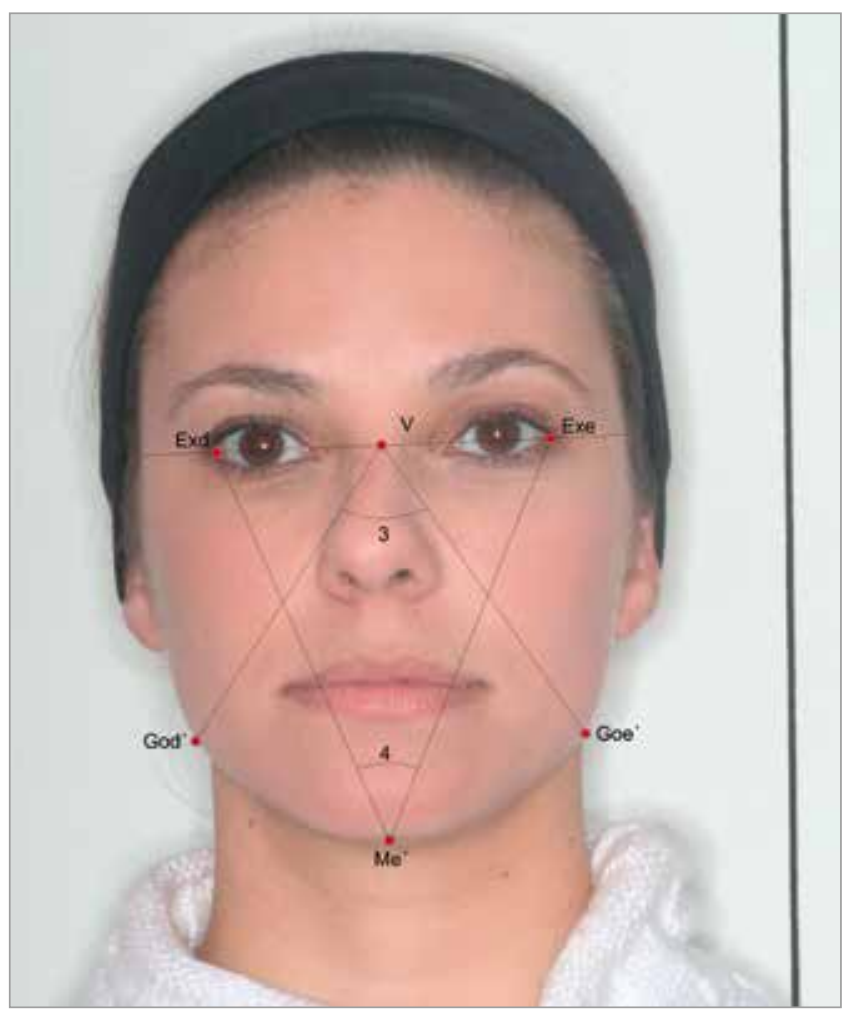

Figure 7 - Angular measures 3 and 4:3) $\vee$ Angle - angle formed by lines extending from $\vee$ to God' point and from $\vee$ to Goe'; 4) Facial aperture modified angle - angle formed by right and left lines extending from Exd to Exe to Me' point. 


\section{RESULTS}

The data found in this research will be described and presented in tables 1 to 5 .

Considering all the evaluators together (five orthodontists, five artists and five laymen), the mean score was calculated for each photograph, ranging from 1 to 9. At this point, it were added the 15 marks given for each individual and calculated the mean value obtained by dividing the sum by the total number of evaluators who constituted the group, disregarding the first decimal point by rounding the scores to the nearest integer value. Thus, to each participant it was given only one score mean, regardless the group of evaluators.

From the mean scores individuals were divided into 3 groups according to the degree of facial attractiveness. Group 2, corresponding to esthetically acceptable, was the one which contemplated the highest percentage of participants, $70.6 \%$ (Table 1).

To check the agreement level between the classifications made by different groups of evaluators (orthodontists, artists and laymen) it was used the Kappa Index of Agreement and the percentage of concordant evaluators. It was observed that the lower concordance was found between laymen and orthodontists, and the highest among laymen and plastic artists (Table 2).

Seventeen linear measurements, 2 proportional and 4 angular, were performed on the groups presented in Tables 3-5. Comparing the means, it was found that only 3 of these variables were statistically significant different, 1 being linear (extension of the lower lip vermilion border) and two angular (angle of facial aperture modified and V angle). In the other measurements no statistically significant differences were found.

\section{DISCUSSION}

Beauty is represented by balance and harmony of facial proportions, including skeletal structures, teeth and soft tissues of the face. Orthodontic treatment frequently aims to preserve our increasing facial characteristics through visible changes on soft tissues. It is important to perform a global evaluation of face, paying attention to the patient's esthetical necessities and not only to the functional and cephalometric matters. This study was developed to evaluate facial attractiveness and the characteristics of female faces in a frontal view through numeric facial analysis.

Regarding the attractiveness, the sample was characterized by 16 individuals esthetically unpleasant (18.8\%), 60 esthetically acceptable (70.6\%) and 9 esthetically pleasant (10.6\%), indicating predominance of the esthetically acceptable standard, which was also found by other authors. ${ }^{11,21,23}$ The smaller group in this study was the esthetically pleasant, just like in the study of Reis ${ }^{23}$ and Morihisa, ${ }^{15}$ demonstrating how hard are the beauty standards imposed by society, many times looking for unreachable ideals.

Facial esthetic is very subjective, thus to perform a reliable rating, the evaluator group has to be as numerous and heterogeneous as possible, trying to avoid individual influences, being composed by people from different academic contexts. In most researches found in literature it were selected orthodontists, plastic artists and/or lay people to evaluate the esthetics of the sample.,10,11,12,13,15,23,29 Following these orientations, in this research the evaluator group selected to classify the sample was composed by 5 orthodontists, 5 plastic artists and 5 lay people of both genders.

Table 1 - Subjective concept of facial esthetics.

\begin{tabular}{cccc} 
Concept & Scores & Number & $\%$ \\
\hline Group 1 - Unpleasants & $1,2,3$ or 4 & 16 & 18.8 \\
Group 2 - Acceptables & 5 or 6 & 60 & 70.6 \\
Group 3 - Pleasant & 7,8 or 9 & 9 & 10.6 \\
Total & 85 & 100.0 & \\
\hline
\end{tabular}

Table 2 - Kappa Index of agreement between groups.

\begin{tabular}{ccccc} 
Evaluators & \% of agreements & Kappa & Interpretation \\
Lay x Plastic artists & 41.2 & 0.2026 & Slight \\
Lay x Orthodontists & 21.2 & -0.0364 & Poor \\
Plastic artists x Orthodontists & 38.8 & 0.1703 & Slight \\
\hline
\end{tabular}


The agreement level between evaluators was assessed through Kappa index and also by the percentage of concordant evaluators, comparing groups in pairs.

Agreement between lay people and orthodontists was considered poor by the Kappa index (-0.0364), indicating only $21.2 \%$ of agreement. Between lay people and artists and then between artists and orthodontists there were a slight agreement, being respectively 0.2026 and 0.1703 , corresponding to $41.2 \%$ and $38.8 \%$ of concordants. So it can be noticed that the lowest agreement was between lay people and orthodontists and the highest between lay people and plastic artists.

The obtained data show that there is little agreement between evaluation, suggesting that the criteria of esthetic appreciation are really subjective,

Table 3 - Descriptive statistic of linear measurements in the study groups ( $\mathrm{mm})$.

\begin{tabular}{|c|c|c|c|c|c|c|c|}
\hline Data & $\mathbf{n}$ & Mean & SD & Minimum & Maximum & Median & p value ${ }^{(1)}$ \\
\hline Lower facial width & 85 & 23.61 & 2,32 & 16.75 & 29.64 & - & 0.378 \\
\hline - Unpleasant & 16 & 24.16 & 2.47 & 20.76 & 29.64 & - & \\
\hline - Acceptable & 60 & 23.59 & 2.33 & 16.75 & 28.46 & - & \\
\hline - Pleasant & 09 & 22.81 & 1.94 & 19.53 & 25.87 & - & \\
\hline Lower lip-mentonian height & 85 & 46.18 & 3.32 & 36.26 & 56.90 & - & 0.056 \\
\hline - Unpleasant & 16 & 47.89 & 3.22 & 44.26 & 56.90 & - & \\
\hline - Acceptable & 60 & 45.89 & 3.14 & 36.26 & 51.07 & - & \\
\hline - Pleasant & 09 & 45.06 & 3.99 & 40.99 & 54.40 & - & \\
\hline Filter length & 85 & 16.96 & 2.25 & 10.98 & 22.24 & - & 0.356 \\
\hline - Unpleasant & 16 & 17.53 & 2.23 & 14.34 & 22.24 & - & \\
\hline - Acceptable & 60 & 16.92 & 2.31 & 10.98 & 21.10 & - & \\
\hline - Pleasant & 09 & 16.19 & 1.85 & 12.85 & 18.52 & - & \\
\hline Upper lip vermillion extension & 85 & 6.67 & 1.27 & 3.16 & 11.00 & - & 0.987 \\
\hline - Unpleasant & 16 & 6.63 & 1.33 & 4.48 & 10.57 & - & \\
\hline - Acceptable & 60 & 6.68 & 1.30 & 3.16 & 11.00 & - & \\
\hline - Pleasant & 09 & 6.63 & 1.12 & 5.12 & 8.44 & - & \\
\hline Lower lip vermillion extension & 85 & 10.95 & 1.73 & 6.67 & 14.49 & - & 0.048 \\
\hline - Unpleasant & 16 & 11.39 & 1.39 & 8.89 & 13.57 & - & \\
\hline - Acceptable & 60 & 10.67 & 1.74 & 6.67 & 14.49 & - & \\
\hline - Pleasant & 09 & 12.01 & 1.78 & 9.48 & 14.00 & - & \\
\hline Mouth height & 85 & 17.60 & 2.59 & 10.83 & 24.39 & - & 0.303 \\
\hline - Unpleasant & 16 & 18.00 & 2.38 & 15.14 & 24.13 & - & \\
\hline - Acceptable & 60 & 17.34 & 2.66 & 10.83 & 24.39 & - & \\
\hline - Pleasant & 09 & 18.63 & 2.38 & 14.58 & 22.41 & - & \\
\hline Commissure line inclination & 85 & 0.94 & 0.76 & 0.00 & 4.09 & 0.82 & $0.141^{(2)}$ \\
\hline - Unpleasant & 16 & 1.19 & 0.65 & 0.05 & 2.05 & 1.20 & \\
\hline - Acceptable & 60 & 0.91 & 0.80 & 0.00 & 4.09 & 0.77 & \\
\hline - Pleasant & 09 & 0.67 & 0.53 & 0.11 & 1.59 & 0.82 & \\
\hline Mouth width & 85 & 50.54 & 3.66 & 42.91 & 59.82 & - & 0.213 \\
\hline - Unpleasant & 16 & 50.34 & 3.25 & 44.68 & 55.98 & - & \\
\hline - Acceptable & 60 & 50.29 & 3.75 & 42.91 & 59.82 & - & \\
\hline - Pleasant & 09 & 52.57 & 3.38 & 47.95 & 57.60 & - & \\
\hline Upper facial height & 85 & 142.40 & 7.07 & 125.26 & 157.77 & - & 0.374 \\
\hline - Unpleasant & 16 & 144.62 & 6.58 & 132.41 & 156.88 & - & \\
\hline - Acceptable & 60 & 141.97 & 7.38 & 125.26 & 157.77 & - & \\
\hline - Pleasant & 09 & 141.37 & 5.42 & 131.53 & 147.33 & - & \\
\hline
\end{tabular}


Table 3 (continuation) - Descriptive statistic of linear measurements in the study groups ( $\mathrm{mm}$ ).

\begin{tabular}{|c|c|c|c|c|c|c|c|}
\hline Data & $\mathbf{n}$ & Mean & SD & Minimum & Maximum & Median & p value ${ }^{(1)}$ \\
\hline Lower facial width & 85 & 113.71 & 7.36 & 95.87 & 131.91 & - & 0.647 \\
\hline - Unpleasant & 16 & 113.25 & 6.80 & 103.53 & 129.46 & - & \\
\hline - Acceptable & 60 & 114.12 & 7.74 & 95.87 & 131.91 & - & \\
\hline - Pleasant & 09 & 111.75 & 5.84 & 101.10 & 121.04 & - & \\
\hline Nose length & 85 & 44.73 & 4.57 & 35.85 & 57.21 & - & 0.195 \\
\hline - Unpleasant & 16 & 46.33 & 6.29 & 37.79 & 57.21 & - & \\
\hline - Acceptable & 60 & 44.16 & 4.19 & 35.85 & 53.11 & - & \\
\hline - Pleasant & 09 & 45.69 & 2.77 & 40.76 & 49.27 & - & \\
\hline Nose width & 85 & 36.20 & 3.01 & 28.86 & 43.89 & - & 0.661 \\
\hline - Unpleasant & 16 & 36.20 & 2.85 & 32.43 & 43.70 & - & \\
\hline - Acceptable & 60 & 36.33 & 3.18 & 28.86 & 43.89 & - & \\
\hline - Pleasant & 09 & 35.34 & 2.13 & 31.70 & 38.01 & - & \\
\hline Right eye width & 85 & 29.51 & 1.77 & 25.60 & 33.36 & - & 0.283 \\
\hline - Unpleasant & 16 & 29.96 & 1.73 & 26.65 & 33.09 & - & \\
\hline - Acceptable & 60 & 29.32 & 1.77 & 25.60 & 33.36 & - & \\
\hline - Pleasant & 09 & 30.04 & 1.72 & 26.78 & 32.43 & - & \\
\hline Left eye width & 85 & 29.85 & 1.92 & 26.02 & 34.52 & - & 0.347 \\
\hline - Unpleasant & 16 & 30.28 & 1.84 & 26.55 & 34.52 & - & \\
\hline - Acceptable & 60 & 29.65 & 1.94 & 26.02 & 34.26 & - & \\
\hline - Pleasant & 09 & 30.38 & 1.90 & 27.48 & 33.06 & - & \\
\hline Intercanthal width & 85 & 33.37 & 2.63 & 27.41 & 37.90 & - & 0.624 \\
\hline - Unpleasant & 16 & 32.79 & 3.01 & 27.46 & 37.19 & - & \\
\hline - Acceptable & 60 & 33.51 & 2.59 & 27.41 & 37.90 & - & \\
\hline - Pleasant & 09 & 33.45 & 2.25 & 29.95 & 35.54 & - & \\
\hline Middle face height & 85 & 70.56 & 5.85 & 57.42 & 87.83 & - & 0.215 \\
\hline - Unpleasant & 16 & 72.87 & 7.94 & 59.07 & 87.83 & - & \\
\hline - Acceptable & 60 & 69.99 & 5.32 & 57.42 & 83.97 & - & \\
\hline - Pleasant & 09 & 70.26 & 4.40 & 63.71 & 74.96 & - & \\
\hline Lower facial height & 85 & 69.76 & 4.89 & 56.86 & 80.88 & - & 0.080 \\
\hline - Unpleasant & 16 & 72.02 & 4.20 & 66.67 & 80.88 & - & \\
\hline - Acceptable & 60 & 69.45 & 4.90 & 56.86 & 78.26 & - & \\
\hline - Pleasant & 09 & 67.85 & 5.12 & 60.50 & 78.00 & - & \\
\hline
\end{tabular}

OBSERVATION: It is recommended to use median for very high SD values. (') ANOVA; ( $\left.{ }^{2}\right)$ Kruskal-Wallis.

Table 4 - Descriptive statistics of proportional measurements in the study groups.

\begin{tabular}{|c|c|c|c|c|c|c|c|}
\hline Data & $\mathbf{n}$ & Mean & SD & Minimum & Maximum & Median & p value ${ }^{(1)}$ \\
\hline Facial Index & 85 & 85.03 & 3.85 & 75.10 & 94.74 & - & 0.229 \\
\hline - Unpleasant & 16 & 86.52 & 4.30 & 77.99 & 94.03 & - & \\
\hline - Acceptable & 60 & 84.70 & 3.59 & 76.91 & 94.74 & - & \\
\hline - Pleasant & 09 & 84.58 & 4.48 & 75.10 & 89.12 & - & \\
\hline Facial height proportion & 85 & 1.01 & 0.09 & 0.81 & 1.26 & - & 0.677 \\
\hline - Unpleasant & 16 & 1.01 & 0.12 & 0.81 & 1.17 & - & \\
\hline - Acceptable & 60 & 1.01 & 0.09 & 0.84 & 1.26 & - & \\
\hline - Pleasant & 09 & 1.04 & 0.09 & 0.92 & 1.23 & - & \\
\hline
\end{tabular}

(1) ANOVA. 
Table 5 - Descriptive statistics of angular measurements in the study groups.

\begin{tabular}{|c|c|c|c|c|c|c|c|}
\hline Data & $\mathbf{n}$ & Mean & SD & Minimum & Maximum & Median & p Value \\
\hline Angle of facial symmetry & 85 & 1.45 & 1.05 & 0.01 & 4.46 & 1.24 & $0.618^{(1)}$ \\
\hline - Unpleasant & 16 & 1.66 & 1.07 & 0.32 & 3.67 & 1.26 & \\
\hline - Acceptable & 60 & 1.43 & 1.06 & 0.01 & 4.46 & 1.25 & \\
\hline - Pleasant & 09 & 1.19 & 0.96 & 0.34 & 3.31 & 1.16 & \\
\hline $\begin{array}{l}\text { Facial aperture modified } \\
\text { angle }\end{array}$ & 85 & 44.07 & 1.96 & 36.53 & 48.71 & - & $0.021^{(2)}$ \\
\hline - Unpleasant & 16 & 42.92 & 2.42 & 36.53 & 45.71 & - & \\
\hline - Acceptable & 60 & 44.25 & 1.70 & 40.17 & 48.18 & - & \\
\hline - Pleasant & 09 & 44.88 & 2.12 & 42.14 & 48.71 & - & \\
\hline V Angle & 85 & 71.02 & 3.48 & 62.51 & 80.38 & - & $0.011^{(2)}$ \\
\hline - Unpleasant & 16 & 68.98 & 4.07 & 62.51 & 75.66 & - & \\
\hline - Acceptable & 60 & 71.72 & 3.27 & 63.05 & 80.38 & - & \\
\hline - Pleasant & 09 & 69.98 & 1.97 & 67.80 & 73.47 & - & \\
\hline $\begin{array}{l}\text { Symmetry of left and } \\
\text { right side of the face }\end{array}$ & 85 & 1.35 & 0.93 & 0.01 & 3.56 & 1.20 & $0.470^{(1)}$ \\
\hline - Unpleasant & 16 & 1.47 & 1.01 & 0.05 & 3.50 & 1.38 & \\
\hline - Acceptable & 60 & 1.26 & 0.89 & 0.01 & 3.56 & 1.10 & \\
\hline - Pleasant & 09 & 1.69 & 1.10 & 0.03 & 3.50 & 1.67 & \\
\hline
\end{tabular}

OBSERVATION: For very high SD values it is recommended to use the median. (1) Kruskal-Wallis; ( ${ }^{2}$ ) ANOVA.

confirming the findings of Martins, ${ }^{11}$ besides showing a tendency of orthodontists being more complacent, giving higher scores to the participants.

A possible explanation would be the concern of orthodontist with the symmetry, balance and facial proportions, not only with isolated shapes. Other factor is the fact that orthodontists know the facial limitations, being capable to recognize pleasant characteristics even among small imperfections. In this research the laymen were the most critical on the evaluation and the plastic artists assigned intermediate scores.

The more specialized and related to esthetics the evaluator groups, the higher were the scores assigned to the sample. However, these findings disagree with those presented in a study evaluating the attractiveness of facial profile and stated that, in general, clinicians (orthodontists and maxillofacial surgeons) were more strict about facial esthetics than non-clinician (plastic artists and laymen), although all groups have agreed on the choice of most attractive profile. ${ }^{31}$ Thus, for more conclusive results about the degree of agreement between the assessors and the tendency of esthetic judgment between groups with different areas of expertise, it is important to emphasize that the ideal would be a group with a larger number of participants than the used in this research.

\section{Numeric facial analysis}

In five variables it were found important differences and these were related to the lower facial third and the facial standard. In the group esthetically unpleasant it was observed a tendency to more elongated faces with increased lower third, which is considered very unfavorable to the facial balance, especially in female subjects.

In the present research the mean found for the vermillion extension of lower lip was of $10.95 \pm 1.73 \mathrm{~mm}$. This variable presented higher values for the esthetically pleasant group, with a mean value of $12.01 \pm 1.78 \mathrm{~mm}$. For the esthetically acceptable and unpleasant groups, the means were respectively $11.39 \pm 1.39 \mathrm{~mm}$ and $10.67 \pm 1.74 \mathrm{~mm}$. The difference found between values on the 3 groups was considered statistically significant. This fact can be explained by the current preference for more thick lips spread by media.

The lower lip length was higher on the groups esthetically unpleasant. 
The general mean found was $46.18 \pm 3,32 \mathrm{~mm}$. In the esthetically pleasant group the mean was of 45.06 $\pm 3.99 \mathrm{~mm}$. For esthetically acceptable and unpleasant groups the mean values were respectively $45.89 \pm$ $3.14 \mathrm{~mm}$ and $47.89 \pm 3.22 \mathrm{~mm}$. However, there was no statistically significant difference The same way, the lower facial height was also higher for esthetically unpleasant group. In this research, the mean was 69.76 $\pm 4,89 \mathrm{~mm}$. The mean value found for the esthetically pleasant group was of $67.85 \pm 5.12 \mathrm{~mm}$; in the esthetically acceptable group $69.45 \pm 4.90 \mathrm{~mm}$ and in the esthetically unpleasant $72.02 \pm 4.20 \mathrm{~mm}$. It was not observed statistically significant difference. Both lower lip length and lower facial height were higher in the esthetically unpleasant group. These two variables are related to a long lower third of the face.

The facial aperture modified angle was lower in the esthetically unpleasant group, being that a significant difference. The mean value obtained in this study was of $44.07 \pm 1.96^{\circ}$. In the pleasant group the mean was $44.88 \pm 2.12^{\circ}$, in the acceptable group was $44.25 \pm 1.70^{\circ}$ and in the unpleasant was $42.92 \pm 2.42^{\circ}$. Lower values for this angle indicate a longer and thinner face, what agrees with the results obtained for the lower lip length and for lower facial height that also showed a tendency of esthetically unpleasant group presenting longer faces.

The $\mathrm{V}$ angle is related to the facial type. A lower value indicates a longer face and a higher value indicates a wider face. This angle presented significant difference compared to other groups, being higher for the esthetically acceptable group, indicating a tendency for a more horizontal facial growth for the individuals composing this group.

It was not found any other statistically significant difference for the other variables when comparing the 3 groups. This result demonstrated that the numeric facial analysis used isolated was not able to detect the attractiveness standard since beauty criteria are subjective, being influenced by cultural, racial, age and gender factors. ${ }^{11}$

This way, an orthodontic treatment just aiming to adequate to proposed standards by facial and cephalometric analysis do not guarantee an ideal beautiful face, but it is important that orthodontists and surgeons have the esthetics standards of orientation..$^{26,27}$

Instead of seeking absolute values, the harmony, balance and proportionality associated to the esthetic perception of the patient should substantiate the diagnosis and treatment plan, so the esthetic benefits of the treatment is noticed by everyone. .,21,24,27,29 $^{2}$

\section{CONCLUSIONS}

1) The sample was characterized by 16 individuals esthetically unpleasant 18.8\%), 60 esthetically acceptable (70.6\%) and 9 esthetically pleasant (10.6\%), indicating dominance for the esthetically acceptable standard.

2) Obtained data showed little agreement between evaluation of orthodontists, plastic artists and lay people. The more specialized and related to esthetics the evaluator group, the higher were the scores assigned to the participants of the research. This way, orthodontists were the most complacent, followed by plastic artists, being the laymen the most critical evaluators.

3) In the evaluation of facial measurements, it was observed that in only 3 variables there were statistically significant difference, which were: Lower lip vermillion border, facial aperture modified angle and $\mathrm{V}$ angle. In two measurements it was observed adjacent probability: Lower lip length and anterior facial height.

4) The numeric facial analysis, when used isolated, seems to not be sensitive to detect attractiveness standards since they are highly subjective, being influenced by cultural, racial, age and gender factors. 


\section{REFERENCES}

1. Ackerman JL, Proffit WR. Soft tissue limitations in orthodontics: treatment planning guidelines. Angle Orthod. 1997;67(5):327-36.

2. Angle EH. Classification of malocclusion. Dent Cosmos. 1899 Apr;41(2):24864, 350-357.

3. Arnett GW, Bergman RT. Facial keys to orthodontic diagnosis and treatment planning - Part I. Am J Orthod Dentofacial Orthop. 1993 Apr;103(4):299-312.

4. Bishara SE, Jorgensen GJ, Jakobsen JR. Changes in facial dimensions assessed from lateral and frontal photographs. Part I - Methodology. Am J Orthod Dentofacial Orthop. 1995 Oct;108(4):389-93.

5. Colombo VL. Análise facial frontal em repouso e durante o sorriso em fotografias padronizadas [Monografia de Especialização]. Curitiba (PR): Associação Brasileira de Odontologia; 1998

6. Cooke MS, Wei SH. The reproducibility of natural head posture: A methodological study. Am J Orthod Dentofacial Orthop. 1988 Apr;93(4):280-8.

7. Cox NH, Van Der Linden FPGM. Facial Harmony. Am J Orthod. 1971 Aug;60(2):175-83.

8. Farkas LG, Kolar JC. Antropometrics and art in the aesthetics of women's faces. Clin Plast Surg. 1987 Oct;14(4):599-616.

9. Ferrario VF, Sforza C, Miani A, Tartaglia G. Craniofacial morphometry by photografic evaluations. Am J Orthod Dentofacial Orthop. 1993 Apr;103(4):327-37.

10. Foster EJ. Profile preferences among diversified groups. Angle Orthod. 1973 Jan;43(1):34-40.

11. Martins LF. Análise fotométrica em norma frontal, de adultos, brasileiros, leuodermas, não tratados ortodonticamente, classificados pela estética facial [Dissertação]. São Bernardo do Campo (SP): Universidade Metodista de São Paulo Faculdade de Odontologia; 2001.

12. Matoula S, Pancherz H. Skeletofacial morphology of attractive and nonattractive faces. Angle Orthod. 2006 Mar;76(2):204-10.

13. McKoy-White J, Evans CA, Viana G, Anderson NK, Giddon DB. Facial profile preferences of black women before and after orthodontic treatment. Am J Orthod Dentofacial Orthop. 2006 Jan;129(1):17-23.

14. Moorrees CF. Natural head position - a revival. Am J Orthod Dentofacial Orthop. 1994 May;105(5):512-3.

15. Morihisa O. Avaliação comparativa entre agradabilidade facial, Proporção àurea $e$ padrão facial [Dissertação]. São Bernardo do Campo (SP): Universidade Metodista de São Paulo, Faculdade de Odontologia; 2006.

16. Moss J P, Linney $A D$, Lowey MN. Uso das técnicas tridimensionais na estética facial. In: Sadowski PL, Peck S, King G, Laskin DM. Atualidades em Ortodontia. São Paulo: Premier; 1997. p. 89-97.
17. Motoyoshi M, Namura S, Arai HY. A three-dimensional measuring system for the human face using three-directional photography. Am J Orthod Dentofacial Orthop. 1992 May;101(5):431-40.

18. Nanda RS, Ghosh J, Bazakidou E. Three-dimensional facial analysis using a vídeo imaging system. Angle Orthod. 1996;66(3):181-8.

19. Nguyen DD, Turley PK. A quantitative method for the evaluation of the soft-tissue facial profile. Am J Orthod Dentofacial Orthop. 1998 Aug;114(2):208-17.

20. Nguyen DD, Turley PK. Changes in the Caucasian male facial profile as depicted in fashion magazines during the twentieth century. Am J Orthod Dentofacial Orthop. 1998 Aug;114(2):208-17.

21. Peck H, Peck S. A concept of facial esthetics. Angle Orthod. 1970 Out;40(4);284-317.

22. Reche R. Análise do perfil facial em fotografias padronizadas. R Dental Press Ortod Ortop Facial. 2002 Jan-Fev;7(1):37-45.

23. Reis $\mathrm{SAB}$. Análise facial numérica e subjetiva do perfil e análise da relação oclusal sagital de Brasileiros, adultos, leucodermas não tratados ortodonticamente [Dissertação]. São Bernardo do Campo (SP): Universidade Metodista de São Paulo, Faculdade de Odontologia; 2001.

24. Ricketts RM. Planning treatment on the basis of the facial pattern and an estimate of its growth. Angle Orthod. 1957 Jan;27(1):14-37.

25. Suguino R, Ramos AL, Terada HH, Furquim LZ, Filho OGS. Análise Facial. R Dental Press Ortod Ortop Facial. 1996 Set-Out;1(1):86-107.

26. Verona J. Análise facial frontal masculina em repouso e durante o sorriso, métodos manual e computadorizado, em fotografias padronizadas. [Monografia de Especialização]. Curitiba (PR): Associação Brasileira de Odontologia; 2004

27. Wuerpel EH. On facial balance and harmony. Angle Orthod. 1937;7:81-9.

28. Silva NCF, Aquino ERB, Mello KCFR, Mattos JNR, Normando D. Habilidade de ortodontistas e leigos na percepção de assimetrias da mandíbula. Dental Press J Orthod. 2011 July-Aug;16(4):38.e1-8.

29. Reis SAB, Abrão J, Claro CAA, Capelozza Filho L. Avaliação dos fatores determinantes da estética do perfil facial. Dental Press J Orthod. 2011 JanFeb;16(1):57-67.

30. Pereira AL, De-Marchi LM, Scheibel PC, Ramos AL. Reprodutibilidade da posição natural da cabeça em fotografias de perfil de crianças de 8 a 12 anos, com e sem o auxílio de um cefalostato. Dental Press J Orthod. 2010 Jan-Fev;15(1):65-73.

31. Almeida MD, Farias $A C R$, Bittencourt MAV. Influência do posicionamento sagital mandibular na estética facial. Dental Press J Orthod. 2010 Mar-Apr;15(2):87-96. 